\title{
The influence of demographics, socio-economics, and the environment on the preferences and behavior of middle-class Muslims in forming the potential for a halal hospital
}

\author{
L. Latifah*, Fatmah, A.I. Mawardi \& I. Ritonga \\ Universitas Islam Negeri Sunan Ampel, Surabaya, Indonesia
}

\begin{abstract}
This study was designed to unveil the influence of demographic, socio-economic, and environmental factors on the preferences and behavior of middle-class Muslims toward the potential of a halal hospital in Surabaya, Indonesia. A simple random sampling technique was used with a total of 217 respondents in this study. To analyze the data, the Structural Equational Model (SEM) from the AMOS statistical software was used. Findings revealed that demographics, socioeconomics, and the environment significantly influenced respondents' preferences. This study also discovered that preferences towards behavior, preferences towards the potential of a halal hospital, and the actual behavior towards the potential of a halal hospital are correlated. Arguably, a halal hospital's potential is central, which is around $75 \%$ as measured by the level of preference and behavior of middle-class Muslims who have different demographic, social, economic, and environmental characteristics.
\end{abstract}

Keywords: Middle-class Muslim, demographic, socio-economic, environment, potential halal hospital

\section{INTRODUCTION}

Middle-class consumers have been emerged as a marketing revolution in Indonesia in the last five years. According to the Central Statistics Agency, the increase in the middle-class population with expenditure per day of 2-20 USD in Indonesia has now reached around 8-9 million people annually (Central Statistics Agency 2013), so that the number of Indonesia's middle-class population has reached 130 million. This phenomenon has significant market potential as this population has more income. The potential of middle-class consumers in Indonesia, especially Muslim consumers, can be seen from the rise of Muslim middle-class markets in Islamic banking with a growth of $40 \%$ since 1991. Looking at this advancement, it is thus central to consider the principle of halal products or services, including in health service sectors.

Surabaya, the capital city of East Java province in Indonesia, is the second-largest city in Indonesia after Jakarta, with a population of 3,016,344 people. This percentage includes the middle class Muslim population of 2,489,690 people (82.54\%). The high number of middle-class Muslims in Surabaya allows us to find out how their preferences and behavior would affect halal hospital services and health care. The investigation of their preferences and behaviors is essential since most of them consume halal products in the city. Preference in this study includes choices that consumers prefer. A preference ranks all situations or conditions starting from the most preferred to the least preferred. Consumer preference is the nature of the desire of consumers to choose existing products or services. Preferences in the Islamic perspective are also well explained. According to Madrasir and Khoiruddin (2012), several principles should be aligned with the Islamic perspective, such as

*Corresponding author 
(1) the excellence goods and services, (2) the usefulness or use of goods and services consumed,

(3) the appropriate quantity of goods and services consumed.

Behavior is an action or deed of an organization that can be observed and can even be learned. Consumer behavior is an action involved in the acquisition and consumption of products ad services, including the processes that precede and follow consumption (Husein 2005). Understanding consumer behavior more accurately will make it easier for manufacturers to prepare the right marketing techniques to deal with consumer behavior. According to Etta and Sofia (2013), three basic concepts of consumer behavior include (1) the need for some basic satisfaction or desire to satisfy specific needs, (2) the demand for a specific product supported by the ability and willingness to buy it.

In general, there are two approaches to defining the middle class: the relative approach and the absolute approach (Easterly 2001; Yuswohadi 2014). One of them is used by Asia Development Bank, which defines the middle class as people with a per capita expenditure range of 2-20 USD, which is divided into lower middle classes (2-4 USD), middle classes (4-10 USD), and upper middle class (10-20 USD). A Sharia hospital (also known as a "halal hospital") has been outlined by the fatwa of the National Sharia Council of the Indonesian Ulema Council No. 107/DSN-MUI/X/2016 with guidelines for Hospital Administrators to use based on Sharia Principles. The public may need an explanation of the guidelines for the organization of hospitals based on Sharia principles and legal provisions.

The fatwa regarding Sharia hospitals is the basis for analyzing its potential in the present study, including (1) the provisions related to contracts and legal issues, (2) the provisions related to hospital services, (3) the provisions related to the use of drugs, food-beverages, cosmetics, and used goods, (4) the provisions related to the placement, use, and development of hospital funds, and (5) the provisions related to safeguarding religion, the soul, intellect, heredity, and treasure as explained in maqashid al-Shariah or the purpose of Sharia enactment. This study sought to investigate: (1) the influence of demographic, social, economic, and environmental variables on the preferences of middle-class Muslims in shaping the potential of a Halal Hospital, (2) the preferences' effect on the behavior, and (3) the effect of the preferences and behavior on the potential of Halal Hospital.

\section{METHODS}

Garnered through Structural Equation Modeling (SEM) (Jogiyanto 2011) with AMOS statistical programs, the study sites were based in Surabaya City areas covering West Surabaya, South Surabaya, North Surabaya, Central Surabaya, and East Surabaya. "Middle-Class Muslims" (hence-forth, "respondents") includes 3,016,344 people, with $82.54 \%$ or $2,489,690$ people with expenditures above 2 USD per day. Also, 2,117,482 (85.05\%) respondents are Muslim residents. We recruited 217 respondents using a simple random sampling technique. The analysis was carried out after previously measuring the model using validity and reliability tests. Conceptually, If the construct is unidimensional, it is analyzed using first-order confirmatory factor analysis. In contrast, if it is multidimensional, it is analyzed using a second-order confirmatory factor (Notoatmodjo 2012).

\section{RESULTS AND DISCUSSION}

This study documents that the composition of the middle-class Muslims' age in Surabaya is 140 adults 26-45 years of age in a total of 217 respondents, with as many as teenagers $20.3 \%$ of the sample and elderly people representing $15.2 \%$. Meanwhile, the factor of seniority or the emergence of the older group is more dominant in channeling preferences, including in making decisions about their health. It is natural that this age group is less dominant in giving preference, including making decisions. This is in accordance with what Müller-Arteaga et al. (2020) has explained: that there is a difference of position based on age which will change the old and young groups who are different in terms of channeling preferences and making decisions. According to Wiyono (2006), age influences a person's active participation. 
In the context of the demographic factor, the composition between women and men is not much different or almost the same, with 104 men (47.9\%) and 113 women (52\%) out of 217 respondents. Although the difference is small, this gender difference is significant in influencing the decision or preference. This finding is consistent with SEM model measurements that have a positive loading factor of 1.00. Theoretically, gender influences the desire and ability of the community, especially the middle-class Muslims, to participate in a community. According to Mappiare (1994), men and women differ in their perspectives in dealing with a problem. Thus, the Male group has the privilege compared to the female group. Thus, male groups have more opportunities to participate.

In the context of socio-economic factors, most Muslims in Surabaya have attained tertiary education $(83.4 \%)$, and $15 \%$ of them educated are less educated. These levels of education affect the changes in attitudes and behavior in healthy living. A higher level of education enables people to absorb information and implement it in their daily behavior and lifestyle, especially in the case of halal hospitals. Economic factors in this study are explained by two aspects, namely the work variable and respondent expenditure variable. The Job variable or type of business is the work occupied by respondents or the middle-class community in Surabaya. The expenditure variable is the amount of respondents' expenditure for the needs of respondents (Kotler 2007).

According to the Indonesian Central Statistics Agency, the average expenditure per capita is the costs incurred for consumption per household member for a month, both from gifts, purchases, and income. The average expenditure per capita of Surabaya's middle-class Muslim community is included in the lower-middle-class group, which is $75.6 \%$ or 164 people out of 217 total respondents surveyed. The lower middle class's high level will economically increase the number of products and services, including health services such as halal hospitals as there will be more and more Muslim middle-class money to be spent (Zarmani et al. 2015).

In the context of the environment and hospital facilities, $80 \%$ of the respondents are neutral regarding health services that have been visited, both functionally, emotionally, and spiritually with 5.709 and CR 1.780 (>0.5), and a loading factor of 10.164 (>0.7). It implies that the work variable is very large. It can be seen that $22.6 \%$ of the respondents or around 49 people out of 217 total respondents are self-employed, then $19.4 \%$ are traders, $17.1 \%$ are private employees, $13.8 \%$ run businesses in the services, $9.2 \%$ have their own production, $0.5 \%$ are in agriculture and fisheries, and only $3.2 \%$ are serving as civil servants, military, and police (Rosyada 2015; Veithzal 2014).

Our study also portrayed the middle-class Muslims' preference variable on the halal hospital potential. The results showed there was a significant influence between the preferences and behavior of the Muslim middle class on the potential of Halal Hospital in Surabaya. As explained by Kotler (2010), in his book Marketing Management, preferences mean preferences, choices, or something that consumers prefer. Preferences in this study were documented from Muslims in Surabaya regarding a halal hospital that is in accordance with Sharia principles. The organization and service of a hospital that is in accordance with the principles of Sharia are in accordance with the fatwa of DSN MUI (2018) No.107 concerning the implementation of Sharia hospitals in which there are legal bases in accordance with the Qur'an and Al-Hadith and the principles of $f i q h$. The background is that there must be a fatwa about Sharia hospitals.

The basic principles of Sharia that form the basis of research in shaping the preferences of middle-class Muslim communities in the city of Surabaya in this study are the existence of legal agreements and personnel, hospital services, payment transactions, the use of medicines and food and drinks, cosmetics and used goods and maqashid al-syariah, namely protecting religion, reason, life, descent and wealth. This preference was built by taking into account the demographic, social, economic, and environmental factors of the middle-class Muslim community of Surabaya City.

Middle-class Muslims in this study are demographically mature in age with a per capita expenditure level mostly in the lower middle class, mostly with high education and have a universalist lifestyle. As explained by Yuswohadi (2014) in his book Markething to the Middle Class Muslim, which divides the lifestyle of middle class Muslims into 4, namely apathis, rationalist, conformist and universalist. In this study, the universalist lifestyle was $37 \%$, the apathetic lifestyle was $35 \%$, the rationalist lifestyle was $19 \%$ the conformist lifestyle was $9 \%$. 
The universalist lifestyle is the lifestyle of the largest middle class in Surabaya with the characteristics of tolerance, open-mindedness, upholding universal values and inclusive of values outside of Islam. From the characteristics of Surabaya's Muslim middle-class consumers, it can be concluded that Surabaya's Muslim middle-class consumers are Muslim consumers who have broad knowledge or insight into global mindsets and have technological literacy and, on the other hand, firmly carry out Islamic values in everyday life. They understand and apply Islamic values substantively, not just normatively. They are more willing to accept differences and tend to uphold universal values, they are not ashamed to be different, and they tend to accept the differences of others.

We concluded that the strength and ability of the middle-class Muslims in Surabaya is very large in relation to realizing it is halal hospital. By understanding middle-class Muslim preferences in Surabaya, investors or policymakers will be able to design appropriate strategies to respond to consumer expectations. In the SEM statistical test, the effect of preference on potential was SE: $0.021, \mathrm{CR} 4.325$, and a loading factor of 0.092 . This means that the construct of preferences as measured by demographic, social, economic, and environmental variables significantly influences the potential for halal hospitals. This means that the constructs of the preferences of middle-class Muslims who have different demographic, social, economic, and environmental backgrounds are related to halal hospitals or hospitals based on Islamic Sharia principles that are related to legal contracts and personnel, home services sickness, payment transactions, the use of drugs and food and drinks, cosmetics and used goods, the protection of religion, the guarding of reason, the protection of souls, the guarding of children and the protection of possessions have very high potential.

\section{CONCLUSION}

This study has revealed that demographic, social, economic, and environmental variables have a significant influence on the preferences of middle-class Muslims in Surabaya toward the halal hospital. This is indicated by the demographic value of SE: $5.433 \mathrm{CR}$ : 0.573 , social value of SE: 2,473 CR: 0.787, economic value of SE: 4,032 CR: $-1,338$, and environmental value of SE: 2,111 CR: 0.0558. Also, this study uncovered that middle-class Muslims' preferences in Surabaya have a significant influence on their behavior. This is indicated by the value of SE: 0.024 CR: 7,614. More importantly, their preferences and behavior significantly influence the potential of the halal hospital. This is indicated by the preference variable with a value of SE: $0.083 \mathrm{CR}: 0.774$ and P: 0.000 and the behavioral variables value of SE: 0.083, CR: 7.774, and P: 0.000 .

\section{REFERENCES}

Central Statistics Agency. 2013. Profile kesehatan Indonesia. Kemenkes Republik Indonesia.

DSN-MUI. 2018. Pedoman Penyelenggara RumahSakit Berdasarkan Prinsip Syariah, https://dsnmui.or.id.

Easterly, William. 2001. The Middle-Class Consensus and Econommic Development, Journal of Economic Growth, vol. 6. Swedia: EconPapers Orebro University.

Husein, Umar. 2005. Riset Pemasaran dan Perilaku Konsumen, Jakarta: PT Gramedia Pustaka Utama dan. Jakarta Busnis Researct Center.

Jogiyanto. 2011. Konsep dan Aplikasi Struktural Eqution Modeling, Yogyakarta: UPPSTIM YKPN.

Kotler, Philip. 2000. Manajemen Pemasaran, Jakarta: Prehalindo.

Kotler, Philip, Keller L K. 2007. Manajemen Pemasaran, Jakarta: Pearson Education Inc.

Madrasir and Khoirudin. 2012. Etika Bisnis Dalam Islam, Lampung: Seksi Penerbitan Fakultas Syariah IAIN Raden Intan.

Mappiare, Andi. 1994. Psikologi Orang Dewasa Bagi Penyesuaian Dan Pendidikan, Surabaya: Usana Off-set printing.

Müller-Arteaga, C., Martín Martinez, A., Padilla-Fernández, B., Blasco Hernández, P., Espuña Pons, M., Cruz, F. \& López-Fando, L. 2020. Position of the Ibero-American Society of Neurourology and Urogynecology in relation to the use of synthetic suburethral meshes for the surgical treatment of female stress incontinence. Neurourology and Urodynamics, 39(1), 464-469. 
Notoatmodjo, Soekidjo. 2012. Metodologi Penelitian Kesehatan. Jakarta. Rineka Cipta.

Rosyada, Dede. 2015. Seminar on Rumah Sakit Syari'ah 2015, FKIK UIN Syarif Hidayatullah Jakarta.

Veithzal. 2014. Manajemen Sumber Daya Insani. Jakarta. PT Raja Grafindo Persada.

Wiyono, Slamet, 2006. Manajemen Potensi Diri, Jakarta: PT Grasindo.

Yuswohadi. 2014. Marketing to the Middle-Class Muslim, Jakarta: PT Gramedia Pustaka Utama.

Zarmani, Nur Farhani, M. Anuar, Shaikh M. Saifuddeen. 2015. Potensi Pemba ngunan Industri Peranti Halal Terhadap Penjanaan Sektor Pelancongan Perubahan Halal di Malaysia. Proceedings of the 2nd International convention on Islamic Management. 


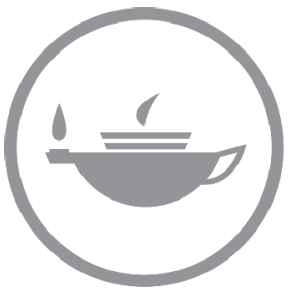

Taylor \& Francis Taylor \& Francis Group

http://taylorandfrancis.com 